\title{
Microbial, phytochemical, toxicity analyses and antibacterial activity against multidrug resistant bacteria of some traditional remedies sold in Buea Southwest Cameroon
}

Moses Njutain Ngemenya ${ }^{1,3^{*}}$, Ghogo Gail Rinda Djeukem', Kennedy Dohjinga Nyongbela², Petuel Ndip Ndip Bate', Smith Borakaeyabe Babiaka ${ }^{2}$, Elvis Monya ${ }^{3}$ and Rudolf Khundou Kanso ${ }^{1}$

\begin{abstract}
Background: Traditional medicine remedies are commonly used for treatment of diverse ailments including bacterial infections. The activity against resistant bacteria and safety of some remedies sold as anti-infective treatments in market places in Buea, Southwest Cameroon were investigated as potential alternative treatment to counter increasing antibiotic resistance.

Methods: Ten remedies were purchased, their components documented and microbial load estimated. Methanol extracts of the remedies were tested for antibacterial activity by disc diffusion and microdilution. Cytotoxicity was evaluated on monkey kidney epithelial cells (LLC-MK2) while acute oral toxicity was done in BALB/C mice for the bactericidal extract. Extracts were further analysed using phytochemical tests.

Results: All the remedies had microbial loads above the acceptable limit of $10^{5} \mathrm{CFU} / \mathrm{g}$. The highest activity was produced by extracts of four remedies (TP 1, 2, 4, 6a, 6b) against all clinical isolates among which three were active against four control strains. Zones of inhibition ranged from 8 to $27 \mathrm{~mm}$. Two of the four extracts produced zones $\geq 20 \mathrm{~mm}$ against multidrug resistant clinical isolates of Citrobacter freundii and Escherichia coli but were less active compared to Gentamycin positive control $(P<0.0001-0.0014)$. The most active extracts also recorded minimum inhibitory concentrations of 1 to $4 \mathrm{mg} / \mathrm{mL}$. One of them (TP2) was bactericidal against a clinical isolate of methicillin-resistant Staphylococcus aureus with a minimum bactericidal concentration of $8 \mathrm{mg} / \mathrm{mL}$. Extracts of six remedies did not show cytotoxicity and no mortality or adverse effect was recorded in the acute oral toxicity test. Phytochemical screening showed the most active extracts contained relatively high amounts of alkaloids and flavonoids.
\end{abstract}

Conclusion: Only four of the eight remedies tested showed activity against multidrug resistant bacteria suggesting some of these remedies may not be effective against bacterial infections. Production and handling methods should be improved and the product quality controlled to ensure biosecurity. The remedies which were both active and nontoxic should be further investigated including in vivo experiments to assess their efficacy.

Keywords: Resistance, Antibacterial, Traditional medicine remedy, Toxicity, Phytochemistry

\footnotetext{
* Correspondence: njutain.moses@ubuea.cm

'Department of Biochemistry and Molecular Biology, Faculty of Science,

University of Buea, P.O. Box 63, Buea, South West Region, Cameroon

${ }^{3}$ Biotechnology Unit, Faculty of Science, University of Buea, P.O. Box 63, Buea,

South West Region, Cameroon

Full list of author information is available at the end of the article
}

(c) The Author(s). 2019 Open Access This article is distributed under the terms of the Creative Commons Attribution 4.0 International License (http://creativecommons.org/licenses/by/4.0/), which permits unrestricted use, distribution, and reproduction in any medium, provided you give appropriate credit to the original author(s) and the source, provide a link to the Creative Commons license, and indicate if changes were made. The Creative Commons Public Domain Dedication waiver (http://creativecommons.org/publicdomain/zero/1.0/) applies to the data made available in this article, unless otherwise stated. 


\section{Background}

Pathogenic microorganisms (bacteria, viruses, parasites and fungi) contribute significantly to the global disease burden. In particular, bacterial infections account for high morbidity and mortality with respiratory and diarrhoeal diseases (caused by bacteria), and tuberculosis featuring among the leading causes of death. Furthermore, communicable diseases account for more than 50\% of annual mortality in the lower income countries like Cameroon [1]. Presently resistance to antibiotics is threatening chemotherapy of bacterial infections. It has led to the emergence of extensively drug-resistant and pandrugresistant phenotypes in a good number of bacterial species and has been documented in virtually all antibiotic classes $[2,3]$. This situation has been compounded by the slow pace of development of new antibiotics whereby no new classes have been introduced into clinical use in the last two decades [4] except for the recently discovered teixobactin which is undergoing development [5]. The infectious disease burden is highest in developing countries particularly in Sub-Saharan Africa, necessitating high antibiotic use which in turn leads to high levels of resistance [6]. Overcoming the antibiotic resistance onslaught requires discovery and development of new efficacious antibiotics and alternative treatments based on natural products among other approaches.

Traditional medicines or remedies are widely used as alternative or complementary treatment to pharmaceutical products and the global market is growing rapidly [7]. These remedies serve as a primary source of healthcare for treatment of many ailments including infectious diseases. However, some of these remedies have many limitations which include unascertained quality, safety, efficacy, lack of regulation among others [7].Various remedies are routinely sold in public places and local markets in Cameroon and are widely consumed as in most developing countries [8]. Another limitation is a gross lack of information on their composition due to no independent scientific data on their production. A few studies on such remedies have shown a mixed picture. One study of herbal products reported considerable antibacterial activity indicating potential therapeutic benefit [9], whereas another found weak or no antibacterial activity alongside significant bacterial contamination [10]. Furthermore, a study reported no antibacterial activity in four products [11]. Toxicity has been reported for a good number of herbal products particularly hepatoxicity; this is possible because this is the first major organ exposed to these products consumed principally by the oral route at unregulated doses [12].

Most studies on traditional remedies have been limited to in vitro experiments; in vivo efficacy studies are rare despite findings of significant activity in vitro $[9,13]$.
Significant antiviral activity was reported in vitro and in vivo in mice for a crude extract of a complex herbal preparation formulated from three antiviral plants [14]. Commonly used commercial antimalarial herbal preparations in Ghana were found to show chemosuppressive activity in vivo in Plasmodium berghei infected mice [15]. An approved study involving humans recorded good antibacterial activity in vitro for Plantago lanceolata herbal tea used in European countries for the local treatment of oral or pharyngeal irritations; and also significant antibacterial activity in vivo in human subjects when used as a mouth rinse [16]. These findings justify in vivo efficacy studies of traditional medicine preparations which have shown significant activity in vitro to further assess their therapeutic potential.

This study therefore embarked on investigating the microbial content, phytochemical composition, antibacterial activity and toxicity of selected anti-infective traditional medicine remedies sold in local markets in Buea municipality, Southwest Cameroon. This was aimed at evaluating the suitability of these products as alternative antibacterials; and to identify remedies which could be further developed into improved traditional medicine therapeutics.

\section{Methods}

\section{Study design}

This was a laboratory-based experimental study. A selection of traditional medicine remedies were purchased based on information provided by the sellers on the infectious diseases treated. The bacterial loads of the preparations were determined to ascertain their microbial safety. Clinical isolates and control strains of bacteria were characterised for antibiotic susceptibility to identify resistant strains. Methanol crude extracts of the powders were prepared, phytochemical constituents determined and together with the liquid preparations (not extracted) were screened for activity against the characterised bacteria. Toxicity of active extracts was investigated on a cell line and in vivo in mice. Experimental data were analysed by comparison with reference data.

\section{Collection of traditional remedies}

We approached sellers of traditional medicine remedies in the local markets (Muea and Central markets) in Buea municipality, Southwest Cameroon, who consented to provide information on their remedies displayed for sale. Information on the name, source, disease(s) treated, component(s) of the remedy and their local name(s) were noted. Ten anti-infective remedies were purchased. Where taxonomic nomenclature of component(s) was provided, this was crosschecked in online plant databases and publications on ethnobotanical surveys in the area of origin of the remedy. The seller or respondent was requested to 
provide specimens (leaves, seeds, and flower of plants) for identification. Preliminary identification of the samples was done by botanists, Professor Chuyong George and Dr. Neba Godlove in the Department of Plant and Animal Physiology, University of Buea, Cameroon. The identities were confirmed by Mr. Ndive Elias using voucher specimens in the Biodiversity and Conservation Centre in Limbe and the National Herbarium of Cameroon in Yaounde and the voucher specimen numbers noted. Where the taxonomic names of the components could not be established such remedies were excluded from the study; but their identification will be pursued further to the source of the product subsequently.

\section{Determination of microbial content of remedies}

Presence of bacterial contaminants in the remedies was determined as described [10]. Five dilutions of 100, 50, 25,10 and $1 \%(\mathrm{v} / \mathrm{v})$ of the liquid remedy were made. For the powders, $10 \mathrm{mg}$ of each was put in $1 \mathrm{~mL}$ of $0.85 \%$ saline, vortexed and allowed to stand. The supernatant was collected and diluted same as liquid remedies. Then $100 \mu \mathrm{L}$ of each dilution was uniformly spread on nutrient agar and incubated (DHP-9052, England) at $37^{\circ} \mathrm{C}$ for $24 \mathrm{~h}$. The number of colony forming units (CFUs) were counted and the microbial load calculated in CFUs/g or CFUs/mL. Gram staining was done for microscopic analysis as described [17] using a loop of cells and visualized under oil immersion.

\section{Preparation of extracts and phytochemical analysis}

Extracts of the remedies were prepared as described [18]. Briefly, weighed amounts (14 to $80 \mathrm{~g}$ ) of the powders were macerated three times in methanol for $72 \mathrm{~h}$ with intermittent stirring, filtered and the filtrate concentrated by rotary evaporation (Buchi Rotavapor R200, Switzerland). The extracts were dried at room temperature and stored at $4{ }^{\circ} \mathrm{C}$ until used. Phytochemical analysis was performed for each extract to determine chemical classes of secondary metabolites present in them and their relative amounts based on qualitative observations produced by specific chemical tests for alkaloids, flavonoids, steroids, tannins and triterpenoids [19].

\section{Source and characterisation of bacteria}

Ten resistant strains of nine pathogenic bacteria species (Citrobacter freundii, Citrobacter youngae, Enterobacter cloacae, Escherichia coli, Proteus mirabilis, Proteus vulgaris, Providencia rettgeri, Salmonella typhi, Salmonella sp. and Methycillin-resistant Staphylococcus aureus (MRSA) were obtained from clinical specimens in Buea Regional Hospital annex, a regional referral health facility in the Southwest region of Cameroon. The cells were characterized by bacteriologists of the hospital by microscopy, susceptibility to reference antibiotics, appropriate culture methods and biochemical tests using the API 20E kit (Biomerieux SA, France). Pure stocks of cells were then stored in $10 \%$ glycerol in Mueller Hinton broth (Liofilchem, Italy) at $-20^{\circ} \mathrm{C}$ during the study period. The following control strains were obtained from BEI Resources and American Type Culture Collection (USA): Escherichia coli (NR 32771), P. aeruginosa (ATCC 27853), Staphylococcus aureus (NR-46003), Staphylococcus epidermidis (NR-46376), Salmonella enterica (NR-515) and Salmonella enterica (NR-4311).

For the purpose of this study, the clinical isolates were re-tested for antibiotic susceptibility to determine the magnitude of their resistance, together with the control strains. For experimental use, working near the freezer the stored cells were retrieved, the frozen stock rapidly scraped using an autoclaved toothpick and deposited on the surface of nutrient agar; and the stock returned immediately into the freezer. A wire loop was flamed and then used to streak on nutrient agar. Susceptibility was done on the clinical isolates as described by the Clinical and Laboratory Standard Institute [20], using discs of 12 standard antibiotics (Liofilchem, Italy), from eight chemical classes selected for this study: Amikacin $(30 \mu \mathrm{g})$, Ceftriaxone $(30 \mu \mathrm{g})$, Cefuroxime $(30 \mu \mathrm{g})$, Cefotaxime $(30 \mu \mathrm{g})$, Ciprofloxacin $(5 \mu \mathrm{g})$, Chloramphenicol $(30 \mu \mathrm{g})$, Gentamicin $(10 \mu \mathrm{g})$, Imipenem $(10 \mu \mathrm{g})$, Nitrofurantoin $(300 \mu \mathrm{g}), \quad$ Norfloxacin $(10 \mu \mathrm{g}), \quad$ Tetracycline $(30 \mu \mathrm{g})$, Trimethoprim $(5 \mu \mathrm{g})$.

\section{Determination of antibacterial activity of extracts}

All experiments were performed under sterile conditions using sterilized glassware and materials. Freshly subcultured bacterial cells were used in all experiments. The disc diffusion test was performed as described [18] with some modifications. Stock solutions of the extracts (10 mg/100 $\mu \mathrm{L}$ dimethylsufoxide, DMSO) were prepared while the liquid remedies were tested undiluted. Bacterial suspension (0.5 McFarland) was spread on Mueller Hinton agar (Liofilchem, Italy) and allowed for 3-5 min to dry. Six millimetre sterile Whatman filter paper discs (number 9) were gently fixed at labelled positions on the agar surface. Then $10 \mu \mathrm{L}$ of test solution ( $1 \mathrm{mg}$ extract) was transferred onto each disc. Positive (appropriate standard antibiotic) and negative (10 $\mu \mathrm{L}$ DMSO) controls were included, the plates kept for $30 \mathrm{~min}$ at room temperature, incubated as above and zones of inhibition measured.

The minimum inhibitory concentrations (MIC) of extracts were determined using the microdilution method as described [18] with one modification: experimental changes in microtitre plate wells were recorded by spectrophotometry. A stock solution of each extract was prepared $(40 \mathrm{mg}$ dissolved in $200 \mu \mathrm{L}$ DMSO and $800 \mu \mathrm{L}$ 
Mueller Hinton broth added); then diluted to obtain test solutions from 40 to $1 \mathrm{mg} / \mathrm{mL}$. The assay was set up in a 96 well microtitre plate in duplicate wells as follows: $50 \mu \mathrm{L}$ test solution, $130 \mu \mathrm{L}$ Mueller Hinton broth followed by $20 \mu \mathrm{L}$ bacterial cell suspension $\left(6 \times 10^{5} \mathrm{CFU} /\right.$ $\mathrm{mL}$ final density). Positive $(20 \mu \mathrm{g} / \mathrm{mL}$ Gentamicin $)$ and negative $(0.85 \%$ saline $)$ controls were included. Final test concentrations were $10,8,6,4,2,1,0.5$ and $0.25 \mathrm{mg} / \mathrm{mL}$ respectively containing $5 \%$ DMSO. The optical densities (ODs) of wells were read, the plate incubated as above and the OD read again at $595 \mathrm{~nm}$ (Emax-Molecular Devices Corporation, USA).

The MIC was calculated from \% growth of bacteria relative to the negative control using the formula below:

$$
\text { \% Growth }=\frac{\text { Change in OD of Test Substance }}{\text { Change in OD of Negative Control }} \times 100 \text {. }
$$

where change in $\mathrm{OD}=\mathrm{OD}$ at $24 \mathrm{~h}-\mathrm{OD}$ at $0 \mathrm{~h}$. MIC is taken as the lowest concentration at which \% growth becomes approximately constant with no further decrease in growth. To determine minimum bactericidal concentration (MBC), a 1:10 dilution in fresh broth of MIC well contents were re-incubated and percentage growth calculated from ODs before and after incubation. The lowest concentration without bacterial growth was recorded as $\mathrm{MBC}$ using the formulas: change in $\mathrm{OD}=\mathrm{OD}$ at $24 \mathrm{~h}$ $\mathrm{OD}$ at $0 \mathrm{~h}$ and

$$
\% \text { Growth of bacteria cells }=\frac{\mathrm{OD} \text { at } 24 \mathrm{hr}-\mathrm{OD} \text { at } 0 \mathrm{hr}}{\mathrm{OD} \text { at } 0 \mathrm{hr}} \times 100
$$

\section{Cytotoxicity test}

The cytotoxicity of the extracts was investigated as described [21] using monkey kidney epithelial cells, LLCMK2 Original (ATCC ${ }^{\bullet} \mathrm{CCL}^{\mathrm{nt}}$ ), (Virginia, USA). All reagents were from Sigma Aldrich (USA). The cells were cultured to confluence in complete RPMI-1640 medium, $\mathrm{CCM}$ (containing $\mathrm{NaHCO}_{3}$, supplemented with $25 \mathrm{Mm}$ HEPES, $0.3 \mathrm{~g} \gamma$-irradiated L-glutamine powder, $10 \%$ heat inactivated new born calf serum, 200 units $/ \mathrm{mL}$ penicillin and $200 \mu \mathrm{g} / \mathrm{mL}$ streptomycin and $0.25 \mu \mathrm{g} / \mathrm{mL}$ amphotercin $\mathrm{B}, \mathrm{pH}$ 7.4) in a T-shaped flask in a $5 \% \mathrm{CO}_{2}$ incubator in humidified air at $37^{\circ} \mathrm{C}$ (Heracell 150i, USA). The medium was decanted, washed off twice with incomplete (calf serum-free) RPMI-1640 medium (ICM), and cells dislodged with $\times 5$ trypsin-EDTA. The cells were then centrifuged at $125 \mathrm{x} \mathrm{g}$ for $10 \mathrm{~min}$ (Eppendorf 5810R, Germany). The supernatant was discarded; the cells resuspended in fresh ICM and quantified using a haemocytometer (Hausser Scientific, USA) and an inverted microscope (Nikon Eclipse TS100, China). The cells were diluted to $30,000 / \mathrm{mL}$ with $\mathrm{CCM}, 100 \mu \mathrm{L}$ seeded in a 96-well flat bottom microtitre plate in duplicate and incubated as above for 3 days for cells to grow and become fully confluent.

Stock solutions of extracts $(25 \mathrm{mg} / \mathrm{mL}$ DMSO) were prepared and diluted with CCM to $2 \mathrm{mg} / \mathrm{mL}$ in duplicate microtitre wells. The seeded cells were checked for confluence by microscopy. Then $100 \mu \mathrm{L}$ of extract was transferred into respective wells giving final concentration of $1 \mathrm{mg} / \mathrm{mL}$. Positive (30 $\mu \mathrm{M}$ auranofin) and negative (2\% DMSO in CCM) controls were included. The plates were incubated as above for 5 days with daily microscopic examination for toxicity. Extracts that were cytotoxic were serially diluted in CCM and re-incubated same as above with freshly cultured cells at final extract concentrations of $15-1000 \mu \mathrm{g} / \mathrm{mL}$. Thereafter the medium was discarded and wells decolourised by shaking with ICM (IKA Labortechnik KS125 basic shaker) at $600 \mathrm{rpm}$ for $5 \mathrm{~min}$ three times. Then $100 \mu \mathrm{L}$ of $5 \mathrm{mg} / \mathrm{mL}$ MTT in ICM was added, the plate incubated as above for $30 \mathrm{~min}$ and $100 \mu \mathrm{L}$ DMSO added to dissolve formazan precipitate. Well contents were gently mixed by shaking and optical densities read same as above at 595 $\mathrm{nm}$. Percentage inhibition was calculated using the formula below:

$$
\text { \%Inhibition }=\frac{\text { OD of Negative control-OD of extract }}{\text { OD of Negative control }} \times 100
$$

$\mathrm{CC}_{50}$ of the cytotoxic extract was determined by plotting a graph, using Graph pad prism, of \% inhibition against log of concentration of extracts.

\section{Acute oral toxicity test for TP2 extract}

This was done following guidelines of the Organization for Economic Cooperation and Development version 423 [22]. This was done for the bactericidal extract TP2 as described [23]. Five adult female BALB/c mice (nine weeks old) were selected in the animal house of the study laboratory and the experiment conducted in the adjacent test room. One animal was weighed, fasted overnight (no food; water only), and administered a dose of $2000 \mathrm{mg} / \mathrm{kg}$ body weight by oral gavage from a freshly prepared solution of TP2 in 7\% Tween 80 . The animal was fasted for a further $2 \mathrm{~h}$, then provided food and water. The treated animal was observed for any obvious acute signs of toxicity hourly during the day while the other four were fasted overnight. Following the survival of the treated animal after $24 \mathrm{~h}$, the other four fasted animals were weighed and treated as above and all animals observed for gross changes such as loss of appetite, piloerection, lacrimation, tremors, convulsions, salivation, diarrhoea, mortality and other signs of overt toxicity for 14 days. The animals were then sacrificed by cervical dislocation. 


\section{Data analysis}

Zone diameters recorded in the susceptibility test and antibacterial screening by disc diffusion were interpreted based on CSLI reference data for the corresponding antibiotics [20]. The zone diameters of the extracts were compared with corresponding values for the Gentamycin positive control at a significance of $P<0.05$ using the T-test (data with normal distribution determined with the Kolmogorov-Smirnov-Test) or Welch test (no normal distribution of data). In the microdilution assay, the \% growth of bacteria calculated from optical densities were plotted against concentration of extract, then MIC and MBC interpolated at the lowest of the concentrations at which bacterial growth was near constant and no longer decreasing. Data from cytotoxicity assay was analysed using Graph pad prism version 6.0, the concentration of extract that produced $50 \%$ cytotoxic effect $\left(\mathrm{CC}_{50}\right)$ on Monkey kidney epithelial cells obtained.

\section{Results}

\section{Information on remedies}

Of the ten remedies purchased, two (200 Disease cure and German powder), which could not be identified were excluded from the study. Of the eight remedies investigated, six were powder and two in liquid form. Information on the remedies obtained from the sellers and the corresponding taxonomic information are shown on Table 1. The sources revealed that some remedies originate far from the local markets where sold, within Cameroon and abroad from neighbouring Nigeria and further from the republic of Niger, West Africa. Following solvent extraction of the powders high yields were obtained for most of the extracts ranging from 31 to $81 \%$. The taxonomic information of the plant species contained in four remedies were established as described under the methods section, based on their corresponding names (Madachi, Bagaruwa, Gewaya tsamiya and Gesa) in the Hausa vernacular of the source areas and specimens provided.

\section{Microbial content of remedies}

All eight remedies were contaminated with both Grampositive and negative bacilli and cocci. The bacterial load ranged from $1.8 \times 10^{3}$ to $2.1 \times 10^{5} \mathrm{CFUs} / \mathrm{mg}$ or CFUs/ $\mathrm{mL}$. None had a microbial count within the acceptable range of microbial contamination of $10^{5} \mathrm{CFU} / \mathrm{g}\left(10^{2}\right.$ $\mathrm{CFU} / \mathrm{mg}$ ) for aerobic bacteria as stipulated in the WHO guidelines on the quality of herbal materials [24]. TP3 (Madigest 2) and TP4 (Desert war 2) had the highest microbial counts of $1.8 \times 10^{5} \mathrm{CFU} / \mathrm{mg}$ and $2.1 \times 10^{5} \mathrm{CFU} /$ mg respectively while TP7 (Fever medicine) had the lowest microbial count of $1.8 \times 10^{3} \mathrm{CFU} / \mathrm{mg}$.

\section{Antibiotics susceptibility of bacteria}

Based on reference data (diameter of inhibition zones) for antibiotic susceptibility of the Clinical and Laboratory Standards Institute [20], both the control and clinical isolates were sensitive to the aminoglycosides (Amikacin, Gentamicin), fluoroquinolones (Ciprofloxacin, Norfloxacin), Nitrofurantoin and Chloramphenicol. Resistance was observed for the carbapenem (Imipenem), cephems (Cefotaxime, Ceftraixone, Cefuroxime), folate pathway inhibitor (Trimethoprim) and Tetracycline. Each bacterial strain was resistant to at least one antibiotic. Multidrug resistance was confirmed in nine of the ten clinical isolates (resistant to at least one antibiotic of three chemical classes) [2], presented on Table 2. Proteus vulgaris, Providencia rettgeri and Salmonella typhi were the most resistant to 5, 6 and 5 classes of antibiotics respectively. The resistance of the clinical isolate of $S$. aureus to methicillin was confirmed.

\section{Antibacterial activity of remedies}

Extracts of four remedies (TP 1, 2, 4, 6a, 6b) were active against all the clinical isolates. Extracts of three remedies (TP 1, 2, 4, 6a, 6b) were active against at least four of the control strains. All extracts showed activity against S. enterica (NR-515). The liquid remedies (TL 5 and 7) tested undiluted were less active; TL7 showed relatively low activity against only two control strains with no activity against the clinical isolates (Table 3). The zones of inhibition for the extracts ranged from 8 to $27 \mathrm{~mm}$ against 17 to $24 \mathrm{~mm}$ for Gentamycin positive control. Two extracts (TP1 and 4) produced zones $\geq 20 \mathrm{~mm}$ against multidrug resistant clinical isolates (Citrobacter freundii and Escherichia coli). The highest zone against clinical isolates was $24 \mathrm{~mm}$ produced by TP1 against $E$. coli; and the highest zone against control strains was $27 \mathrm{~mm}$ produced by TP4 against Staphylococcus aureus (NR-46003). However, when zone diameters were compared using statistical tests, Gentamycin was more active than each of the four most active extracts $(P<0.0001-0.0014)$. Four of the eight remedies (TP 1, 2, 4, 6) recorded MIC values from 1 to 4 $\mathrm{mg} / \mathrm{mL}$. TP1 had the lowest MIC of $1 \mathrm{mg} / \mathrm{mL}$ against $S$. typhi clinical isolate shown on Table 4 . Of these 4 extracts, only TP2 showed MBC at $8 \mathrm{mg} / \mathrm{mL}$ against MRSA. The MBC:MIC ratio gave a value of 2 which is less than 4 indicating bactericidal effect of TP2 against this strain (Table 4) [25]. Figure 1 shows inhibition of growth at higher concentrations of TP2 with higher growth at the lower concentrations giving the MIC and $\mathrm{MBC}$ values of 4 and 8 $\mathrm{mg} / \mathrm{mL}$ respectively.

\section{Phytochemical profile of extracts}

The crude extracts and undiluted liquid remedies were found to contain alkaloids, flavonoids, steroids, tannins 
Table 1 Traditional anti-infective remedies purchased in Buea, Cameroon

\begin{tabular}{|c|c|c|c|c|c|}
\hline \multirow{2}{*}{$\begin{array}{l}\text { Product } \\
\text { Name }\end{array}$} & \multirow[t]{2}{*}{ Source/ Use } & \multicolumn{2}{|l|}{ Component(s) } & \multicolumn{2}{|c|}{ Remedy Extract } \\
\hline & & $\begin{array}{l}\text { Family, Species (Voucher } \\
\text { number)/ or Reference }\end{array}$ & $\begin{array}{l}\text { Local name } \\
\text { (part used) }\end{array}$ & $\begin{array}{l}\text { Code } \\
\text { Yield } \\
\text { (\%) }\end{array}$ & $\begin{array}{l}\text { Phytochemical } \\
\text { classes }\end{array}$ \\
\hline \multirow[t]{2}{*}{ Kiankia } & \multirow[t]{2}{*}{$\begin{array}{l}\text { SW Cameroon/ typhoid fever, } \\
\text { malaria }\end{array}$} & $\begin{array}{l}\text { Annonaceae: Annickia chlorantha } \\
\text { (Oliv.) Setten \& Maas (SCA 1043) }\end{array}$ & $\begin{array}{l}\text { Quinine stick } \\
\text { (stem bark) }\end{array}$ & \multirow[t]{2}{*}{$\begin{array}{l}\text { TP1 } \\
50.6\end{array}$} & \multirow{2}{*}{$\begin{array}{l}\text { Alkaloids (3) } \\
\text { Triterpenoids (2) } \\
\text { Flavonoids (1) } \\
\text { Tannins (1) }\end{array}$} \\
\hline & & $\begin{array}{l}\text { Apocynaceae Alstonia boonei De Wild } \\
\text { (SCA 5972) }\end{array}$ & $\begin{array}{l}\text { Milk stick } \\
\text { (stem bark), }\end{array}$ & & \\
\hline Madachi $^{\text {a }}$ & $\begin{array}{l}\text { Nigeria and Niger/ gastritis, } \\
\text { stomach irritation }\end{array}$ & $\begin{array}{l}\text { Meliaceae: Khaya senegalensis (Desv.) } \\
\text { A. Juss) SCA } 6785[40,41]\end{array}$ & $\begin{array}{l}\text { Mahogany } \\
\text { (stem bark) }\end{array}$ & $\begin{array}{l}\text { TP2 } \\
31.0\end{array}$ & $\begin{array}{l}\text { Alkaloids (3) } \\
\text { Triterpenoids (3) } \\
\text { Flavonoids (2) } \\
\text { Tannins (3) }\end{array}$ \\
\hline \multirow{3}{*}{ Madigest 2} & \multirow{3}{*}{$\begin{array}{l}\text { NW Cameroon/ gut infection, } \\
\text { gastritis }\end{array}$} & Liliaceae: Allium sativum (SCA 1143) & Garlic (fruit), & \multirow{3}{*}{$\begin{array}{l}\text { TP3 } \\
62.4\end{array}$} & \multirow{3}{*}{$\begin{array}{l}\text { Alkaloids (3) } \\
\text { Flavonoids (2) } \\
\text { Steroids (3) } \\
\text { Tannins (2) }\end{array}$} \\
\hline & & $\begin{array}{l}\text { Zingiberaceae: Zingiber officinale } \\
\text { (SCA2926) }\end{array}$ & $\begin{array}{l}\text { Ginger } \\
\text { (rhizome) }\end{array}$ & & \\
\hline & & Asphodelaceae: Aloe vera (SCA 713) & Aloe vera (leaves) & & \\
\hline \multirow[t]{4}{*}{$\begin{array}{l}\text { Desert } \\
\text { war } 2\end{array}$} & \multirow{4}{*}{$\begin{array}{l}\text { NW Cameroon/ microbial iinfections } \\
\text { plus gonorrhoea, syphilis, urinary tract } \\
\text { pains }\end{array}$} & $\begin{array}{l}\text { Myrtaceae: Eucalyptus globulus Libille } \\
\text { (SCA 7840) }\end{array}$ & Eucalyptus (leaves) & \multirow[t]{4}{*}{$\begin{array}{l}\text { TP4 } \\
36.3\end{array}$} & \multirow{4}{*}{$\begin{array}{l}\text { Alkaloids (3) } \\
\text { Flavonoids (2) } \\
\text { Steroids (3) } \\
\text { Tannins (1) }\end{array}$} \\
\hline & & Liliaceae: A. sativum (SCA 1143) & Garlic (fruit) & & \\
\hline & & $\begin{array}{l}\text { Araliaceae: Vernonia guineensis } \\
\text { (SCA12431) }\end{array}$ & $\begin{array}{l}\text { Cameroonian } \\
\text { ginseng (rhizome) }\end{array}$ & & \\
\hline & & Asphodelaceae: Aloe vera (SCA 713) & Aloe vera (leaves) & & \\
\hline Bagaruwa $^{a}$ & $\begin{array}{l}\text { North and NW Cameroon/ } \\
\text { Cough }\end{array}$ & $\begin{array}{l}\text { Fabaceae: Acacia nilotica (L.) Willd. } \\
\text { ex Delile (SCA 2973) }[40,42]\end{array}$ & a (stem bark) & TL5 & $\begin{array}{l}\text { Triterpenoids (2) } \\
\text { Flavonoids (3) } \\
\text { Tannins (3) }\end{array}$ \\
\hline $\begin{array}{l}\text { Gewaya } \\
\text { tsamiya }^{a}\end{array}$ & $\begin{array}{l}\text { Niger / typhoid fever, malaria, } \\
\text { yellow fever }\end{array}$ & $\begin{array}{l}\text { Fabaceae: Cassia nigricans Vahl }[40,41] \\
\left(N^{\circ} 5970 / H N C\right)\end{array}$ & a (leaves) & $\begin{array}{l}\text { TP6 } \\
56.8\end{array}$ & $\begin{array}{l}\text { Alkaloids (3) } \\
\text { Triterpenoids (3) } \\
\text { Flavonoids (3) } \\
\text { Steroids (3) } \\
\text { Tannins (3) }\end{array}$ \\
\hline \multirow{4}{*}{$\begin{array}{l}\text { Fever } \\
\text { medicine }\end{array}$} & \multirow[t]{4}{*}{ SW Cameroon/ malaria/typhoid fever } & Labiatae: Ocimum gratissimum (SCA 4764) & Masepu (leaves) & \multirow[t]{4}{*}{ TL7 } & \multirow{4}{*}{$\begin{array}{l}\text { Triterpenoids (2) } \\
\text { Flavonoids (2) } \\
\text { Tannins (2) }\end{array}$} \\
\hline & & Asteraceae: Bidens pilosa (SCA 6352) & Black jack (leaves) & & \\
\hline & & Caricaceae: Carica papaya (SCA 1756) & Paw paw (leaves) & & \\
\hline & & Rutaceae: Citrus aurantifolia (SCA11102) & Limes (fruit) & & \\
\hline Gesa $^{a}$ & North and NW Cameroon/ diarrhoea & $\begin{array}{l}\text { Combretaceae: Combretum } \\
\text { micranthum (SCA 2976) }[40,42]\end{array}$ & a (leaves) & $\begin{array}{l}\text { TP8 } \\
81.5\end{array}$ & $\begin{array}{l}\text { Alkaloids (2) } \\
\text { Triterpenoids (3) } \\
\text { Flavonoids (3) } \\
\text { Tannins (3) }\end{array}$ \\
\hline
\end{tabular}

SW Southwest, NW Northwest, TP Crude extract prepared from powder remedy, TL Liquid remedy used neat without further extraction. ${ }^{\circ}$ Local name in Hausa vernacular [40, 41], Bagaruwa has as synonym Gabaruwa in some reports [41]. Relative amount:- $1=$ low; $2=$ moderate; $3=$ high

and triterpenoids from the phytochemical tests. The four most active extracts (TP $1,2,4,6 \mathrm{a}, 6 \mathrm{~b}$ ) had relatively high amounts of alkaloids and flavonoids (Table 1).

\section{Toxicity of remedies}

The cytotoxicity assay on monkey kidney cells, LLCMK2 Original (ATCC ${ }^{\ominus} \mathrm{CCL}^{\mathrm{ru}}$ ), showed that 2 extracts (TP 3 and 6a) were non-cytotoxic at a high dose of $1000 \mu \mathrm{g} /$ $\mathrm{mL}$ since their percentage inhibition of formazan formation was less than 50\%. Six extracts (TP 1, 2, 4, 6b, 8 and TL7) had $\mathrm{CC}_{50}$ values greater than the cut-off point for lack of cytotoxicity $\left(\mathrm{CC}_{50}>30 \mu \mathrm{g} / \mathrm{mL}\right)$, [26]. One extract (TL5) had $\mathrm{CC}_{50}$ value lower than $30 \mu \mathrm{g} / \mathrm{mL}$ indicating mild cytotoxicity (Table 4). Only piloerection was observed in the first two days in the oral toxicity test for TP2 with no mortality recorded. The body weight of all the animals increased; average body weights at the start and after day 14 were 26.6 and $29.4 \mathrm{~g}$ respectively with an average increase of $2.8 \mathrm{~g}$.

\section{Discussion}

Traditional medicine remedies are commonly sold in local markets in Cameroon and some may serve as alternative therapy for infections caused by multidrug 
Table 2 Susceptibility of bacterial strains to standard antibiotics

\begin{tabular}{|c|c|c|c|c|c|c|c|c|c|c|c|c|c|}
\hline \multirow[t]{2}{*}{ Bacteria Strains } & \multicolumn{12}{|c|}{ Diameter of zone of inhibition (mm) } & \multirow{2}{*}{$\begin{array}{l}\text { Resistant } \\
\text { classes of } \\
\text { antibiotics } \\
\text { (n) }\end{array}$} \\
\hline & $\mathrm{AK}$ & GM & $\mathrm{Cl}$ & NX & $\mathrm{CL}$ & $\mathrm{Nl}$ & $\mathbb{I P}$ & TX & CT & $\mathrm{XM}$ & TR & TE & \\
\hline Citrobacter freundii & 27 & 24 & 30 & 32 & 23 & 25 & - & - & - & - & - & 15 & 3 \\
\hline Citrobacter youngae & 30 & 28 & 31 & 31 & 27 & 25 & - & - & - & - & 11 & - & 3 \\
\hline Citrobacter sp. & 19 & 16 & 20 & 26 & 21 & 22 & - & $17 r$ & - & - & 30 & 16 & 2 \\
\hline Enterobacter cloacae & 23 & 17 & 30 & 30 & 24 & 16 & $15 r$ & $15 r$ & - & - & 27 & - & 3 \\
\hline Escherichia coli & 25 & 18 & - & $10 r$ & 22 & 30 & 25 & - & - & - & - & - & 4 \\
\hline MRSA & 24 & 22 & 35 & 29 & 33 & 24 & ND & $10 r$ & - & ND & 15 & 15 & $3^{b}$ \\
\hline Proteus mirabilis & 20 & 20 & 37 & 36 & - & $14 r$ & - & 23 & - & - & 22 & - & 4 \\
\hline Proteus vulgaris & 20 & 16 & 28 & 30 & 30 & $14 r$ & $15 r$ & 25 & - & - & - & - & 5 \\
\hline Providencia rettgeri & 20 & 19 & 25 & 27 & - & - & - & - & - & - & - & - & 6 \\
\hline Salmonella typhi & 19 & 20 & 25 & 25 & - & 15 & - & - & - & - & - & - & 5 \\
\hline Salmonella sp. & 20 & 15 & 36 & 37 & 23 & 18 & $18 r$ & - & - & - & - & 17 & 3 \\
\hline E. coli ${ }^{\mathrm{a}}$ & ND & 20 & 26 & 30 & 29 & 22 & $8 r$ & $8 r$ & ND & ND & $8 r$ & $8 r$ & 4 \\
\hline P. aeruginosa $a^{a}$ & ND & 24 & 30 & 24 & 18 & 20 & - & 8 & ND & ND & - & 20 & 1 \\
\hline S. enterica ${ }^{a} a$ & ND & 22 & 20 & 28 & 30 & 21 & - & 20 & ND & ND & 22 & 19 & 1 \\
\hline S. enteric $a^{a} b$ & ND & 19 & 29 & 27 & 25 & $9 r$ & $9 r$ & - & ND & ND & $11 r$ & 19 & 3 \\
\hline S. aureus ${ }^{\mathrm{a}}$ & ND & 21 & 22 & 19 & $15 r$ & $12 r$ & $7 r$ & $8 r$ & ND & ND & $7 r$ & 19 & 5 \\
\hline S. epidermidis ${ }^{a}$ & ND & 22 & ND & 29 & 28 & $7 r$ & Or & $10 r$ & ND & ND & 29 & 28 & 3 \\
\hline
\end{tabular}

Antibiotic classes: Aminoglycosides (AK Amikacin, GM Gentamicin), Carbapenems (IP Imipenem), Cephems (CT Cefotaxime, TX Ceftriaxone, XM Cefuroxime), Fluoroquinolones (Cl Ciprofloxacin, NX Norfloxacin), Folate pathway inhibitors (TR Trimethoprim), Nitrofurans (NI Ntrofurantoin), Phenicols (CL Chloramphenicol), Tetracyclines (TE Tetracycline)

${ }^{a}$ Control strains (BEI Resources and ATCC, USA); S. enterica strains $a=(N R-515), b=(N R-4311)$. MRSA: methicillin resistant Staphylococcus aureus; ${ }^{b}$ resistant to methicillin, confirmed by a $0 \mathrm{~mm}$ zone not shown on the table. $r$ and - (zone diameter $=0 \mathrm{~mm}$ ), both indicate resistant strain. $n$ : Number of antibiotic classes to which bacterial strain is resistant based on the reference data [20]; $n \geq 3$, strain is considered multidrug resistant [2].

Table 3 Antibiogram of methanol extracts of anti-infective traditional remedies sold in Buea, Cameroon

\begin{tabular}{|c|c|c|c|c|c|c|c|c|c|c|}
\hline \multirow[t]{2}{*}{ Bacteria } & \multicolumn{10}{|c|}{ Diameter of zone of inhibition (mm) } \\
\hline & $\mathrm{TP1}$ & TP2 & TP3 & TP4 & TP5 & TP6a & TP6b & TP7 & TP8 & GM \\
\hline Citrobacter freundii & 12 & 13 & 10 & 20 & - & 11 & 11 & - & 10 & 23 \\
\hline Citrobacter youngae & 11 & 11 & 11 & 13 & 10 & 10 & 11 & - & - & 23 \\
\hline Enterobacter cloacae & 19 & 12 & 14 & 11 & - & 17 & 16 & - & 10 & 24 \\
\hline Escherichia coli & 24 & 15 & 12 & 13 & 10 & 11 & 12 & - & 15 & 21 \\
\hline MRSA & 15 & - & 10 & 11 & 9 & 11 & 12 & - & 11 & $10^{a}, 37^{b}$ \\
\hline Proteus mirabilis & 15 & 17 & 14 & 13 & 8 & 15 & 15 & - & 9 & 24 \\
\hline Proteus vulgaris & 22 & 11 & 10 & 13 & 9 & 11 & 11 & - & 9 & 17 \\
\hline Providencia rettgeri & 15 & 13 & 13 & 12 & - & 12 & 10 & - & 9 & 20 \\
\hline Salmonella typhi & 13 & 13 & - & 17 & - & 10 & 10 & - & - & $17^{c}$ \\
\hline${ }^{\mathrm{f}}$ E. coli & - & 14 & - & 11 & - & 9 & 11 & 9 & - & 18 \\
\hline${ }^{f} P$. aeruginosa & 15 & 15 & 11 & 16 & 9 & 11 & 11 & - & 10 & 20 \\
\hline${ }^{\text {fS. aureus }}$ & 13 & 12 & 13 & 27 & - & 16 & 11 & - & 13 & 24 \\
\hline${ }^{f}$ S. enterica ${ }^{d}$ & 13 & 11 & 12 & 15 & 13 & 9 & 10 & 12 & 15 & 20 \\
\hline${ }^{f}$ S. enterica ${ }^{e}$ & - & - & - & - & - & - & - & - & - & $8^{\mathrm{a}}$ \\
\hline
\end{tabular}

TP Extract of powder remedy, TL Liquid remedy tested undiluted. Positive controls: GM Gentamicin, a: Norfloxacin; b: Trimethoprim; c: Chloramphenicol. Nd Not Done. -: No inhibition. TP6a: methanol extract residue (deposited below oil layer in extract container), TP6b: oil layer above solid residue of TP6 crude extract. MRSA: methicillin resistant Staphylococcus aureus. ${ }^{f}$ Control strains; $S$. enterica strains $d=(N R-515), e=(N R-4311)$ 
Table 4 MICs, MBC and $\mathrm{CC}_{50}$ of crude extracts of traditional medicine preparations

\begin{tabular}{|c|c|c|c|c|}
\hline \multirow[t]{2}{*}{ Product Name } & \multirow{2}{*}{$\begin{array}{l}\text { Extract } \\
\text { code }\end{array}$} & \multicolumn{2}{|c|}{ Activity (Organism) } & \multirow[t]{2}{*}{$\mathrm{CC}_{50}(\mu \mathrm{g} / \mathrm{mL})$} \\
\hline & & $\begin{array}{l}\text { MIC } \\
(\mathrm{mg} / \mathrm{mL})\end{array}$ & $\begin{array}{l}\mathrm{MBC} \\
(\mathrm{mg} / \mathrm{mL})\end{array}$ & \\
\hline Kiankia & TP1 & $1(\mathrm{ST})$ & - & 652.3 \\
\hline Madachi ${ }^{a}$ & TP2 & 4 (MRSA) & 8 (MRSA) & 689.0 \\
\hline Desert war 2 & TP4 & 4 (MRSA) & - & 218.3 \\
\hline Bagaruwa $^{a}$ & TL5 & - & - & 11.4 \\
\hline Gewaya tsamiya ${ }^{a}$ & TP6b & 4 (PM) & - & 435.2 \\
\hline Fever medicine & TL7 & - & - & 149.2 \\
\hline Gesa $^{a}$ & TP8 & - & - & 502.1 \\
\hline
\end{tabular}

MIC Minimum inhibitory concentration, MBC Minimum bactericidal concentration, $\mathrm{CC}_{50}$ Cytotoxic concentration for $50 \%$ of monkey kidney epithelial cells (LLC-MK2 from ATCC, Virginia, USA).. ST Salmonella. typhi, MRSA Methicillin resistant Staphylococcus aureus, PM Proteus mirabilis.TP6b: oil layer above solid residue of TP6 crude extract. -: no MIC, no MBC recorded in the test concentration range. ${ }^{\mathrm{a}}$ Local name in Hausa vernacular

resistant bacteria or source of new efficacious antibacterial compounds. Three main findings were recorded in this study of eight anti-infective traditional remedies sold in Buea, Cameroon. Firstly, only four (50\%), showed activity against resistant bacteria based on minimum inhibitory concentration (MIC) recorded on at least one bacterial strain. Secondly and contrary to the above, a

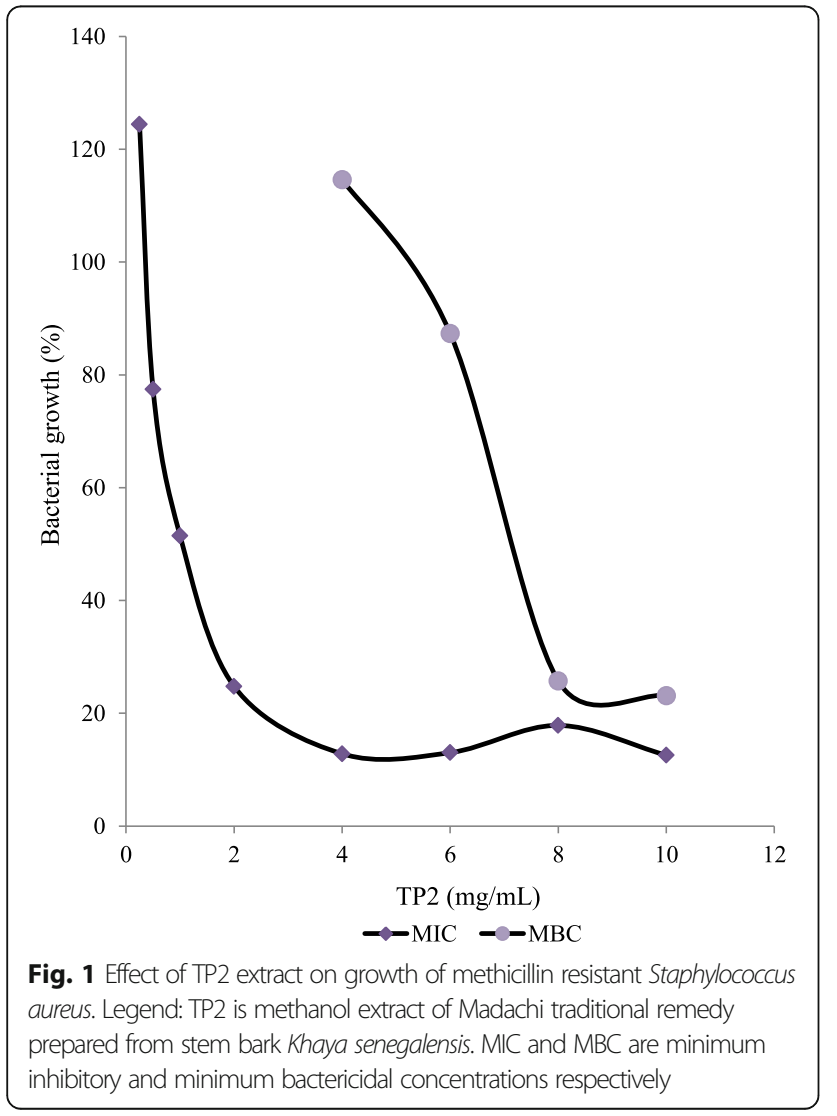

promising finding was made in that six of seven remedies tested for cytotoxicity were not cytotoxic, suggesting that these remedies may not cause serious toxicity when used for therapeutic purposes. Thirdly, all eight remedies were found to be contaminated by bacteria above acceptable limits.

Nine of the ten bacteria isolates tested for antibiotic susceptibility were multidrug resistant. This finding confirmed that of the medical laboratory of the Buea Regional Hospital where they were isolated from clinical specimens and first tested for antibiotic susceptibility (Table 2). These data also confirm findings of previous studies in the study area which reported high levels of resistance in Citrobacter freundii, Enterobacter cloacae, P. aeruginosa and Proteus vulgaris, whereby more than $50 \%$ of isolates from clinical specimens were resistant to antibiotics [27]. The information provided by sellers of the remedies indicates that all the remedies are used to treat bacterial infections among others (Table 1), thereby justifying the screening of these remedies for antibacterial activity against multidrug resistant strains.

Overall, the four most active extracts (TP 1, 2, 4, 6a, $6 \mathrm{~b})$ showed bacteriostatic activity, and also showed the highest activity against an individual bacteria strain in both the disc diffusion test and the MIC assay. These extracts produced the highest zones ranging from $16 \mathrm{~mm}$ for TP6b to $27 \mathrm{~mm}$ for TP4, in the disc diffusion test. However, when all the zones for each extract were considered (Table 3$)$, they were significantly $(P<0.0001-$ 0.0014) lower than those of the Gentamycin positive control suggesting the extract are less active than Gentamycin. These four extracts also produced the lowest MICs $(1 \mathrm{mg} / \mathrm{mL}$ for TP1 and $4 \mathrm{mg} / \mathrm{mL}$ for the others) showing consistency in their activity in the disc and microdilution assays (Tables 3 and 4). Furthermore, one of them (TP2) also recorded a $\mathrm{MBC}$ value $(8 \mathrm{mg} / \mathrm{mL})$ with the MIC:MBC ratio equal to 2 (being less than 4 ) indicating bactericidal activity [25], (Fig. 1). The findings of this study show that the four most active remedies are potential alternative or complementary antibacterials for treatment of infections of resistant bacteria. However, activity was observed for only four of eight remedies suggesting some of the remedies may not be sufficiently efficacious in clinical infections. They should be further investigated using in vivo experiments to evaluate the efficacy of the remedies.

The cytotoxicity test showed that six of the remedies have a low risk of toxicity as seen from their $\mathrm{CC}_{50}$ values of 149 to $689 \mu \mathrm{g} / \mathrm{mL}$ (Table 4), which are much higher than the cut-off point for lack of cytotoxicity $\left(\mathrm{CC}_{50}>\right.$ $30 \mu \mathrm{g} / \mathrm{mL}$ ), [26]. When the United States National Cancer Institute plant screening program criterion for cytotoxic $\left(\mathrm{CC}_{50}\right.$ is $\left.\leq 20 \mu \mathrm{g} / \mathrm{mL}\right)$ is considered, only one extract TL5 $\left(\mathrm{CC}_{50}=11.4 \mu \mathrm{g} / \mathrm{mL}\right)$ is cytotoxic [28]. This 
finding supports the general view that traditional remedies are safe though this must necessarily be confirmed by experimental data, given the increasing evidence of their toxicity [29]. One of the most active and bactericidal extract TP2, recorded the highest $\mathrm{CC}_{50}(689 \mu \mathrm{g} /$ $\mathrm{mL}$, Table 4) indicating a very high safety margin. This is further supported by findings in the oral toxicity test where no mortality occurred after 14 days at $2000 \mathrm{mg} / \mathrm{kg}$ body weight, with only piloerection observed in the first two days. Piloerection (involuntary erection or bristling of hairs) is likely due to sympathetic stimulation involving body heat or temperature regulation mechanisms or due to serotonin release [30].

Whereas the toxicity data for almost all the remedies are favourable, the microbial contamination is the reverse being higher $\left(1.8 \times 10^{3}\right.$ to $2.1 \times 10^{5} \mathrm{CFUs} / \mathrm{mg}$ or $\mathrm{mL})$ than the acceptable limit of $10^{5} \mathrm{CFU} / \mathrm{g}\left(10^{2} \mathrm{CFU} /\right.$ $\mathrm{mg}$ ) in herbal materials [24]. Hence the remedies ironically have a potential risk of infection to the consumers. This risk may be averted through neutralization of the microbes by acidic gastric secretion following oral administration which is the principal route for these remedies. A study found high Bacillus spp. contamination $\left(1.2 \times 10^{3}\right.$ to $6 \times 10^{5} \mathrm{CFUs} / \mathrm{g}$ or $\left.\mathrm{mL}\right)$ in ten herbal remedies manufactured by a business entity and sold widely [31]. Similar findings in another study were attributed to poor preparation and handling of these remedies [10]. The distant source of some of the remedies implies a long chain of custody which may aggravate the contamination. At the user end, some of the products are displayed in open containers and even when closed, are sold by rationing from the same stock hence favouring further contamination by the handlers and the surrounding. The preparation and handling of these products therefore needs significant improvement, standardisation and quality control at all stages to commercialization. The distant source also made establishment of the components of two remedies (excluded from the study) daunting and untraceable as the sellers acquire their stock from middlemen who also do not have this information.

Interestingly, the yields of the powder extracts were quite high reaching about $80 \%$ (Table 1), probably due to thorough drying. Phytochemical analysis revealed the most active remedies were rich in alkaloids with also moderate to high amounts of flavonoids and triterpenoids. Antimicrobial activity of extracts of the plants contained in the most active remedies has been reported; phytochemicals of classes mentioned above among others have been detected in them and the structures of some of their bioactive secondary metabolites reported. These include $A$. boonei [32]; K. senegalensis [33]; A. vera [34] and C. nigricans [35]; this study therefore further confirms the reported activities. The activity of the traditional remedy (Madachi) is likely accounted for by one or more of the compounds detected in the TP2 extract as earlier reported for Khaya senegalensis [33]. The possible mechanisms of action of the active extracts will be investigated later. However, some studies have revealed a number of mechanisms of action of extracts on bacteria. These include decrease in bacterial cytoplasmic $\mathrm{pH}$ and disruption of cell wall [36], generation of reactive-oxygen species and membrane damage [37]. Some extracts cause potentiation of the action of antibiotics resulting in a synergistic inhibition of bacterial cell wall synthesis hence afford a possibility of combination therapy with antibiotics in clinical use [38].

\section{Conclusion}

Only four of the eight remedies tested showed activity against multidrug resistant bacteria suggesting some of these remedies may not be effective against bacterial infections. However, most of the remedies have a low risk of toxicity in spite of their high microbial content. The production and handling methods should be improved to prevent microbial contamination; and the remedies subjected to stringent quality control before commercialization to ensure biosecurity. Considering their activity against multidrug resistant bacteria and the low risk of toxicity, further studies should be done including in vivo experiments to assess their efficacy.

\section{Abbreviations \\ $\mathrm{CC}_{50}$ : Concentration which kills 50\% of cells; CCM: Complete culture medium containing serum; CFU: Colony forming units; DMSO: Dimethyl sulfoxide; ICM: Incomplete culture medium lacking serum; MBC: Minimum bactericidal concentration; MIC: Minimum inhibitory concentration; MRSA: Methicillin- resistant Staphylococcus aureus; MTT: A tetrazolium bromide chromogen; OD: Optical density; TL: Code for liquid remedy tested pure; TP: Extract code for powder remedy; WHO: World Health Organization}

\section{Acknowledgments}

This work was done using resources and facilities provided by the University of Buea in the authors departments and the Biotechnology Unit. Dr. Denis Zofou kindly provided some control strains while Mr. Anthony Kukwah of the Buea Regional Hospital Annex provided the clinical isolates of bacteria. We are grateful to Dr. Manfo T.F. Pascal, Department of Biochemistry and Molecular Biology, for assistance with statistical analysis. Mr. Mbaabe Felix of the Life Sciences Laboratory provided technical assistance.

\section{Authors' contributions}

MNN conceived and designed the study, collected and followed up identification of the remedies, supervised the biological experiments and drafted the manuscript, GGRD and PNNB conducted the bench experiments, KDN and SBB performed the chemical analyses and contributed in drafting the manuscript, EM and RKK performed toxicity tests. All authors read and approved the final manuscript.

\section{Funding}

Resources for this work were provided from the University of Buea 2017 budget. The institution played no role in the conduct and publication of this work.

Availability of data and materials

The datasets used and or analysed in this study are available from the corresponding author on reasonable request. 


\section{Ethics approval}

The study in mice was conducted according to the guidelines of the Organization for Economic Cooperation and Development version 423 of 17 December 2001 [22] in compliance with Directive 2010/63/EU of the European Parliament and of the Council of 22 September 2010 on the protection of animals used for scientific purposes [39].

\section{Consent for publication}

Not applicable

\section{Competing interests}

The authors declare no competing interests.

\section{Author details}

${ }^{1}$ Department of Biochemistry and Molecular Biology, Faculty of Science, University of Buea, P.O. Box 63, Buea, South West Region, Cameroon. ${ }^{2}$ Department of Chemistry, Faculty of Science, University of Buea, P.O. Box 63, Buea, South West Region, Cameroon. ${ }^{3}$ Biotechnology Unit, Faculty of Science, University of Buea, P.O. Box 63, Buea, South West Region, Cameroon.

Received: 5 December 2017 Accepted: 13 June 2019

Published online: 26 June 2019

\section{References}

1. World Health Organization. The top 10 causes of death https://www.who.int news-room/fact-sheets/detail/the-top-10-causes-of-death. Accessed 5 Feb 2019.

2. Magiorakos AP, Srinivasan A, Carey RB, Carmeli Y, Falagas ME, Giske CG, et al. Multidrug-resistant, extensively drug-resistant and pandrug-resistant bacteria: an international expert proposal for interim standard definitions for acquired resistance. Clin Microbiol Infect. 2012;18(3):268-81.

3. Ventola CL. The antibiotics resistance crisis. Part 1: causes and threats. P \&T. 2015:4:277-83

4. Bassetti M, Maria M, Chiara T, Augusta A. New antibiotics for bad bug: Where are we? Ann Clin Microbiol Antimicrob. 2013:12:22

5. Piddock LJV. Teixobactin, the first of a new class of antibiotics discovered by iChip technology? J Antimicrob Chemother. 2015:70:2679-80.

6. Essack SY, Desta AT, Abotsi RE, Agoba EE. Antimicrobial resistance in the WHO African region: current status and roadmap for action. J Public Health. 2016;39(1):8-13

7. World Health Organization. WHO Traditional Medicine Strategy 2014-2023. http://www.who.int/medicines/publications/traditional/trm_strategy14_23/ en/. Accessed 4 June 2017. (2013)

8. Fokunang CN, Ndikum V, Tabi OY, Jiofack RB, Ngameni B, Guedje NM, Kamsu-Kom, et al. Traditional medicine: past, present and future research and development prospects and integration in the national health system of Cameroon. Afr J Tradit Complement Altern Med. 2011:8(3):284-95.

9. Tambekar DH, Dahikar SB. Antibacterial potential of some herbal preparation: an Alternative medicine in treatment of enteric bacterial infection. Int J Pharm Pharm Sci. 2010;2(Suppl 4):176-9.

10. Oyetayo VO. Microbial load and antimicrobial property of two Nigerian herbal remedies. Afr J Tradit Complement Altern Med. 2008:5(1):74-8.

11. Osei-Djarbeng SN, Nyarko S, Osei-Asante S, Owusu-Dapaah G. Absence of in-vitro antimicrobial activity of some antimicrobial herbal preparations in the Ghanaian market. J Pharmacogn Phytochem. 2016;5(5):267-70.

12. Abdualmjid RJ, Sergi C. Hepatotoxic Botanicals - An evidence-based systematic review. J Pharm Pharmaceut Sci. 2013;16(3):376-404.

13. Chusri S, Sinvaraphan N, Chaipak P, Luxsananuwong A, Voravuthikunchai SP. Evaluation of antibacterial activity, phytochemical constituents, and cytotoxicity effects of Thai household ancient remedies. J Altern Complement Med. 2014;20(12):909-18.

14. Kim H, Jang E, Kim S-Y, Choi J-Y, Lee N-R, Kim D-S, Lee K-T, Inn K-S, Kim B-J, Lee $\mathrm{J}-\mathrm{H}$. Preclinical evaluation of in vitro and in vivo antiviral activities of KCT-01, a new herbal formula against hepatitis B virus. Evid Based Complement Alternat Med. 2018:1073509. https://doi.org/10.1155/2018/1073509.

15. Wilmot D, Ameyaw EO, Amoako-Sakyi A, Boampong JN, Quashie NB. In vivo efficacy of top five surveyed Ghanaian herbal anti-malarial products. Malar J. 2017;16:103

16. Ferrazzano GF, Cantile T, Roberto L, Ingenito A, Catania MR, Roscetto E, Palumbo G, Zarrelli A, Pollio A. Determination of the in vitro and in vivo antimicrobial activity on salivary Streptococci and Lactobacilli and chemical characterisation of the phenolic content of a Plantago lanceolata infusion. Biomed Res Int. 2015:286817. https://doi.org/10.1155/2015/286817.

17. Cheesbrough M. District Laboratory Practice in Tropical Countries Part II. Cambridge: University Press; 2006. p. 401-2.

18. Mbah JA, Ngemenya MN, Ashime LA, Babiaka SB, Nubed LN, Nyongbela KD, et al. Bioassay-quided discovery of antibacterial agents: in vitro screening of Peperomia volcanic, Peperomia fernandopoioana and Scleria striatinux. Ann Clin Microbiol Antimicrob. 2012;11:10.

19. Ram J, Moteriya P, Chanda S. Phytochemical screening and reported biological activities of some medicinal plants of Gujarat region. J Pharmacogn Phytochem. 2015;4(2):192-8.

20. Clinical and Laboratory Standards Institute. Performance standards for antimicrobial susceptibility testing; twenty second informational supplement M100 - S22. Wayne: Clinical and Laboratory Standards Institute. http://antimicrobianos.com.ar/ATB/wp-content/uploads/2012/11/M100S22E. pdf. Accessed 15 Dec 2016; 2012

21. Nondo RSO, Moshi MJ, Paul Erasto P, Zofou D, Njouendou AJ, Wanji S, et al. Evaluation of the cytotoxic activity of extracts from medicinal plants used for the treatment of malaria in Kagera and Lindi regions,Tanzania. J Appl Pharm Sci. 2015;5(04):007-12

22. Organization for Economic Cooperation and Development. OECD Guideline for testing of chemicals. Version 423 Adopted: 17 December 2001. http:// www.oecd.org/chemicalsafety/testing/ oecdguidelinesforthetestingofchemicals.htm Accessed 4 June 2017

23. Fentahun S, Makonnen E, Awas T, Giday M. In vivo antimalarial activity of crude extracts and solvent fractions of leaves of Strychnos mitis in Plasmodium berghei infected mice. BMC Complement Altern Med. 2017;17:13.

24. World Health Organization. WHO guidelines for assessing quality of herbal medicines with reference to contaminants and residues. http://apps.who.int/ medicinedocs/documents/s14878e/s14878e.pdf. Accessed 10 Dec 2016 (2007).

25. Haas W, Pillar CM, Hesje CK, Sanfilippo CM, Morris TW. Bactericidal activity of besifloxacin against staphylococci, Streptococcus pneumoniae and Haemophilus influenza. J Antimicrob Chemother. 2010;65:1441-7.

26. Malebo HM, Tanja W, Caletal M, Omolo MO, Hassanali A. Antiplasmodial, antitrypanosomal, antileshmanial and cytotoxicity activity of selected Tanzanian medicinal plants. Tanzan J Health Res. 2009:11(4):226-34.

27. Akoachere JFTK, Yvonne S, Akum NH, Esemu NS. Etiologic profile and antimicrobial susceptibility of community-acquired urinary tract infection in two Cameroonian towns. BMC Res Notes. 2012:5:219.

28. Malek SNA, Phang CW, Ibrahim H, Norhanom AW, Sim KS. Phytochemical and cytotoxic investigations of Alpinia mutica rhizomes. Molecules. 2011;16: 583-9.

29. Ifeoma O, Oluwakanyinsola S. Screening of herbal medicines for potential toxicities; 2013. https://doi.org/10.5772/54493.

30. Matsumotoa RR, Seminerioa MJ, Turnerb RC, Robsona MJ, Nguyena L, Millerf $\mathrm{DB}$, et al. Methamphetamine-induced toxicity: an updated review on issues related to hyperthermia. Pharmacol Ther. 2014:144(1):28-40.

31. Shah B, Pokhrel N. Microbial quality and antibacterial activity of herbal medicines. NJST. 2012:13(2):191-6.

32. Adotey JPK, Adukpo GE, Boahen YOB, Armah FA. Review of the ethnobotany and pharmacological importance of Alstonia boonei DeWild (Apocynaceae). ISRN Pharmacol. 2012. https://doi.org/10.5402/2012/587160.

33. Paritala V, Chiruvella KK, Chakradhar Thamminenic C, Ghantad RG, Mohammed A. Phytochemicals and antimicrobial potentials of mahogany family. Rev Bras Farmacogno. 2015:25:61-83.

34. Nejatzadeh-Barandozi F. Antibacterial activities and antioxidant capacity of Aloe vera. Org Med Chem Lett. 2013:3:5

35. Ayo RG. Phytochemical constituents and bioactivities of the extracts of Cassia nigricans Vahl: A review. J Med Plants Res. 2010;4(14):1339-48.

36. Gonelimali FD, Lin J, Miao W, Xuan J, Charles F, Chen M, et al. Antimicrobial properties and mechanism of action of some plant extracts against food pathogens and spoilage microorganisms. Front Microbiol. 2018;(9):1639. https://doi.org/10.3389/fmicb.2018.01639.

37. Tang Q-L, Kang A-R, Lu C-X. Phytochemical Analysis, Antibacterial Activity and Mode of Action of the Methanolic Extract of Scutellaria barbata Against Various Clinically Important Bacterial Pathogens. Int J Pharmacol. 2016;12(2): $116-25$

38. Voukeng IK, Kuete V, Dzoyem JP, Fankam AG, Noumedem JAK, Kuiate JR, et al. Antibacterial and antibiotic-potentiation activities of the methanol extract of some Cameroonian spices against Gram-negative multi-drug resistant phenotypes. BMC Res Notes. 2012;5:299. 
39. Directives. Directive 2010/63/EU of the European Parliament and of the Council of 22 September 2010 on the protection of animals used for scientific purposes. OJ 2010, L 276/33. https://en.wikipedia.org/wiki/EU_ Directive 2010/63/EU. Accessed 4 June 2017.

40. De Fabregues BP. Lexique des noms vernaculaires de plantes du Niger. $2 e$ edition provisoire. 1977. 1977 https://agritrop.cirad.fr/355446/1/document_ 355446.pdf Accessed 9 July 2017

41. Prelude medicinal plants database. http://www.africamuseum.be/ collections/external/prelude/view_plant?pi=02630 Accessed 5 July 2017.

42. Tukur R, Adamu GK, Rabi'u M Al. Indigenous trees inventory and their multipurpose uses in Dutsin-ma area Katsina state. Eur Sci J. 2013;9(11):288-300.

\section{Publisher's Note}

Springer Nature remains neutral with regard to jurisdictional claims in published maps and institutional affiliations.

Ready to submit your research? Choose BMC and benefit from:

- fast, convenient online submission

- thorough peer review by experienced researchers in your field

- rapid publication on acceptance

- support for research data, including large and complex data types

- gold Open Access which fosters wider collaboration and increased citations

- maximum visibility for your research: over $100 \mathrm{M}$ website views per year

At BMC, research is always in progress.

Learn more biomedcentral.com/submissions 